\title{
COMPARATIVE ANALYSIS OF SOME PHENOLIC ACIDS OF IN VITRO AND IN VIVO GROWN PLANT LEAVES OF SALVIA HISPANICA $\begin{array}{ll}\text { M. I. Salih } & \\ & \text { F. M. K. Al Dabagh } \\ & \end{array}$ \\ ${ }^{1}$ Genetic Engineering and Biotechnology institute, University of Baghdad \\ ${ }^{2}$ Ministry of Agriculture maha.salih@ige.unbaghdad.edu.i2
}

ABSTRACT

Several plant species could be produce bioactive compounds, which play a key role in protecting human health, Chia is one of these plant species which has been gaining growing popularity among the traditional medicine groups. In order to sustainably produce plant biomass and its phytochemical content. Numerous biotechnological approaches need to be employed, and elicitation has proven to be a very effective method for increased secondary metabolite production in various in vitro culture. The current research involves the application of various concentrations of $\mathrm{SA}$ as an elicitor with 2,4-D and BAP in callus cultures, and the main aim was to stimulate the accumulation of biomass and phytochemical contents. The results showed that the highest concentration of keamferol and gallic acid compounds in callus of $S$. hispanica were occurred in the treatment with $2 \mathrm{mgl}^{-1}$ 2,4-D and $2 \mathrm{mgl}^{-1} \mathrm{SA}$ in the presence of $0.5 \mathrm{mgl}^{-1} \mathrm{BA}$.

Keyword: Chia, SA, secondary metabolite production, human health

مجلة العلوم الززراعية العراقية - 52:2021 (1):195-189

مقارنة إنتاج بعض المركبات الفينولية من نبات الثيا باستعمال حامض السالسيليك خارج وداخل الجسم الحي

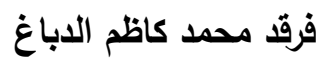

مها ابراهيم صالح

وزارة الززاعة كاطم العاع

معهز الهندسة الوراثية والتقانات الاحيائية

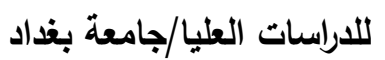

المستخلص

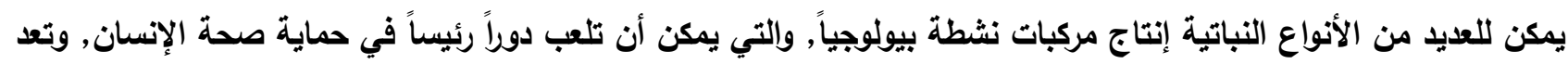
نبات الثيا واحد من هذه الأنواع النباتية التي اكتسبت شعبية متزليدة بين المجاميع الطبية التقليدية, ومن أجل الإنتاج التباج

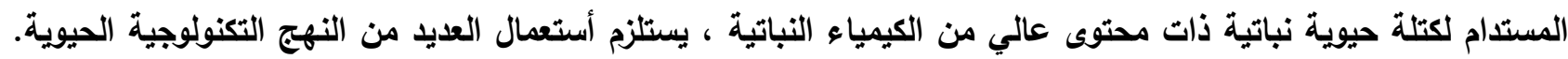

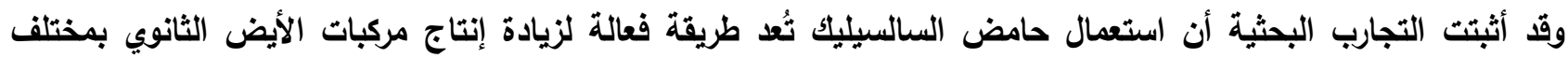

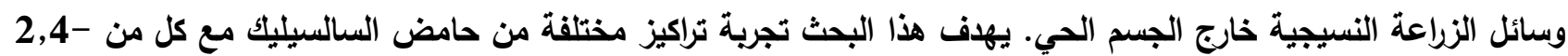
D و BA ودراسة تأثيرها في تحفيز الكالس وزيادة انتاج المركبات الفينولية. أظهرت النتائج ان معاملة الكالس المجهزة بحامض السالسيليك (2ملغ//تر), 2,4-D (2ملف/لتر) و BA (0.5 ملغم/تتر)اعطت أعلى تركيز للمركبين الفينوليين Gallic acid gkeamferol الكلمات المفتاحية: حامض السالسيليك, انتاج المركبات الثانوية. 


\section{INTRODUCTION}

Salvia hispanica L., better known as chia, which belongs to the genus Salvia (2), is a plant food alternative, it is an annual herbaceous plant, native from northern Guatemala southern and Mexico, belonging to the Lamiaceae family. More recently, chia was grown in Argentina, Ecuador Colombia, Australia, Peru, Bolivia and Paraguay for commercial purposes (5). Various parts of this plant are now available commercially for human consumption worldwide, as food supplements. Chia seed is known for its high concentration of dietary fiber, proteins, omega 3 (n-3) Alpha Linolenic Acid (ALA) and phytochemicals, including phenolic compounds $(3,8,17)$. In the absence of effective liver-protective drugs in the modern system of all opathic medical practices, herbal medicines play an important role in health care programs worldwide and interest in herbal treatment of various hepatic conditions is resurgent (25). Phenolic compounds are one of the large and widely distributed classes of secondary metabolites in plants (23), which play a protective role for plants against insects and other organisms. Studies have found that the dietary consumption of bioactive components as phenolic compounds from chia is correlated with a decreased risk of cardiovascular disease and hepatoprotective function (21), and a protective impact against plasma oxidative and obesity-related disease $(9,16)$. It has been documented that modulation of plant growth regulator concentration in culture medium can alter antioxidant properties in plant extracts (20), In addition, information on Salvia hispanica is still quite scarce and, to date, there is a lack of studies on this plant species, in particular the tissue culture research. In the light of that, this was study aimed to extract and purify phenolic content and to characterize the comparative antioxidants activities of both leaf extracts of in vivo and in vitro callus of $S$. hispanica to assess their nutraceutical.

\section{MATERIALS AND METHODS}

This study was carried out from February 2019 to January 2020 in the plant tissue culture laboratory, Genetic Engineering Institute, Baghdad University. Chia seeds were collected from homegrown at Baghdad gardens. Leaf explants were obtained from 30-day old chia seedlings grown under green house.

\section{Explant sterilization and callus induction}

The explants were thoroughly washed under running tap water, treated for 5 minutes with $1 \% \mathrm{NaOCl}$ and 3 drops of Tween 20, followed by distilled sterile rinsing, and then by rinsing with distilled sterile water for 3 times under the cabinet of laminar airflow. The explants of the surface sterilized leaf were taken and trimmed into $1.5 \mathrm{~cm}$ pieces.

Induction and measuring of fresh and dry weight of callus: In order to induce the calli, 2 explants were inoculated into each test tube containing $10 \mathrm{ml}$ MS media (19) fortified with $3 \%$ sucrose and various concentrations of 2,4$\mathrm{D}(1,2,3) \mathrm{mg} / \mathrm{l}$ and or SA $(1,2) \mathrm{mg} / \mathrm{l}$ which they added with the presence of BA $(0.5 \mathrm{mg} / \mathrm{l})$ for all treatments. The medium was solidified with $0.7 \%$ agar, then $\mathrm{pH}$ was adjusted to $5.7 \pm$ 0.1 prior to autoclaving. The culture were maintained at a temperature of $24 \pm 1^{\circ} \mathrm{c}$ under dark. After six weeks, we harvested the calli samples and calculated the fresh weight, later oven dried twenty four hours at $50^{\circ} \mathrm{C}$, then stored for farther analysis

Sample extraction: Enhanced callus with 100 $\mathrm{mg}$ from optimized treatment $\left[2,4-\mathrm{D}\left(2 \mathrm{mgl}^{-1}\right)\right.$ plus SA $\left.\left(2 \mathrm{mgl}^{-1}\right)\right]$ that gave good fresh and dry weight of callus, and $3.0 \mathrm{~g}$ from dried leaves of greenhouse plants were powdered and extracted with methanol in shaker at $30{ }^{\circ} \mathrm{C}$ for 48 hours, in order to produce a crude sample, methanol was evaporated and traces dissolved in water. Those extracts were then used to assess the efficacy of antioxidants $(20,24)$.

HPLC quantification: Chromatographic quantification of phenolic acid was performed with the HPLC method according to Gupta et al. (12). The separation was performed on liquid chromatography with binary delivered pump. Under the optimum conditions and on C18-ODS column, the main compounds were separated. Standard compounds of Apiginine, Catechine, Keamferol, Quercetine and Gallic acid were used, and by applying the following equation, we can quantify the concentrations of active compounds (4): Concentration of compound $=\{$ area of sample $/($ area of standard $)$ $\mathbf{X}$ (concentration of standard) $\mathbf{X}$ (dilution factor)\}. 


\section{Statistical analysis}

Data was analyzed statistically with SAS (Statistical Analysis System). Results are represented as means of ten replicates using a Completely Randomized Design (CRD), means have been compared using the Least Significant Difference test (LSD) at 5\% level.

\section{RESULTS AND DISCUSSION}

\section{Callus induction}

Tables 1, 2 and 3.show inoculated explants on the control medium, with no supplement of any GPRs (the control), did not show any callus initiation. As reported and in order to initiate the calli formation, most explants had exogenous requirements of one or more growth regulators (6). Callus enhancement from $S$. hispanica leaf explants with various 2,4-D concentrations alone or in combinations with SA with presence of BA $(0.5 \mathrm{mg} / \mathrm{l})$ showed different results, callus induction was noted on 2,4-D alone or combined with SA after 30 days of cultivation. Even though, MS medium supported with $2,4-\mathrm{D}(1,2,3) \mathrm{mg} / \mathrm{l}$ or $\mathrm{SA}(1,2) \mathrm{mg} / \mathrm{l}$ were effective in callus induction, MS media supplemented with 2,4-D $(2 \mathrm{mg} / \mathrm{l})$ interacted with $\mathrm{SA}(2 \mathrm{mg} / \mathrm{l})$ produced friable and creamy callus and showed significant increase $(70 \%$ callus induction, $\mathrm{FW}=7.316 \mathrm{mg}, \mathrm{DW}=0.334 \mathrm{mg}$ ). Results of the other researches $(7,18,20)$ suggested that the best stimulated callus was in leav es, also, the combination of auxins and cytokinins led to best stimulation of calli than an individual PGRs. The variance in the content of the PGRs found in plant internal sections may affect in the reaction of plant parts grown by the addition of plant growth regulators, which affects the optimum concentration of cytokinin and auxin mediated callus, or perhaps the both, when applied to the media $(11,13,22)$.

Table 1. Effect of 2,4-D and SA and their interaction on the \% callus induction, after inoculating explants on MS medium for six weeks

\begin{tabular}{|c|c|c|c|c|}
\hline \multirow{2}{*}{$\begin{array}{l}\text { 2,4-D } \\
(\mathrm{mg} / \mathrm{l})\end{array}$} & \multicolumn{3}{|c|}{$\mathbf{S A}(\mathrm{mg} / \mathrm{l})$} & \multirow{2}{*}{ Mean } \\
\hline & 0.0000 & 1.0000 & 2.0000 & \\
\hline 0.0000 & $0.0000^{C}$ & $0.7000^{\mathrm{AB}}$ & $0.4000^{B C}$ & $0.3667^{B}$ \\
\hline 1.0000 & $0.300^{\mathrm{CD}}$ & $0.6000^{\mathrm{AB}}$ & $0.4000^{\mathrm{BC}}$ & $0.4333^{A B}$ \\
\hline 2.0000 & $0.30000^{C D}$ & $0.9000^{A}$ & $0.7000 \mathrm{AB}$ & $0.6333{ }^{A}$ \\
\hline 3.00000 & $0.3000^{\mathrm{CD}}$ & $0.6000^{\mathrm{AB}}$ & $0.4000^{B C}$ & $0.4333^{\mathrm{AB}}$ \\
\hline \multirow[t]{2}{*}{ Mean } & $0.2250^{C}$ & $0.7000^{A}$ & $0.4750^{B}$ & \\
\hline & LSD: $2,4-D=0.2382$ & $\mathrm{SA}=\mathbf{0 . 2 0 6 3}$ & $2,4-D * S A=0.4120$ & \\
\hline
\end{tabular}

Table 2. Effect of 2,4-D and SA and their interaction on mean callus fresh weight (mg), after inoculating explants on solid MS medium for 6 weeks

\begin{tabular}{|c|c|c|c|c|}
\hline \multirow{2}{*}{$\begin{array}{l}2,4-D \\
(\mathrm{mg} / \mathrm{l})\end{array}$} & \multicolumn{3}{|c|}{$\mathrm{SA}(\mathrm{mg} / \mathrm{l})$} & \multirow{2}{*}{$\begin{array}{l}\text { Mean } \\
\text { (mg/l) }\end{array}$} \\
\hline & 0.0000 & 1.0000 & 2.0000 & \\
\hline 0.0000 & $0.0000^{E}$ & $0.0047^{E}$ & $0.0045^{E}$ & $0.0031^{C}$ \\
\hline 1.0000 & $0.0614^{E}$ & $0.0924^{E}$ & $1.9971^{\mathrm{B}}$ & $0.7170^{B}$ \\
\hline 2.0000 & $0.2825^{\mathrm{ED}}$ & $2.1775^{B}$ & $7.3166^{A}$ & $3.2589^{\mathrm{A}}$ \\
\hline 3.0000 & $0.614^{\mathrm{CDE}}$ & $0.9355^{C D}$ & $1.0855^{\mathrm{C}}$ & $0.8783^{B}$ \\
\hline Mean & $0.2395^{C}$ & $0.8025^{B}$ & $2.0009^{A}$ & \\
\hline & 2,4-D & 864 & $2,4-$ & 6693 \\
\hline
\end{tabular}

Table 3. Effect of 2,4-D and SA and their interaction on mean callus dry weight (mg), after inoculating explants on solid MS medium for 6 weeks

\begin{tabular}{|c|c|c|c|c|}
\hline \multirow{2}{*}{ 2,4 D (mg/l) } & \multicolumn{3}{|c|}{$\mathbf{S A}(\mathrm{mg} / \mathrm{l})$} & \multirow{2}{*}{$\begin{array}{l}\text { Mean } \\
(\mathrm{mg} / \mathrm{l})\end{array}$} \\
\hline & 0.00000 & 1.00000 & 2.00000 & \\
\hline 0.0000 & $0.0000^{E}$ & $0.00086^{D}$ & $0.00066^{\mathrm{D}}$ & $0.00051^{B}$ \\
\hline 1.00000 & $0.00451^{D}$ & $0.01686^{D}$ & $0.40173^{A}$ & $0.14103^{A}$ \\
\hline 2.00000 & $0.00428^{D}$ & $0.12111^{C D}$ & $0.33400^{\mathrm{AB}}$ & $0.15313^{A}$ \\
\hline 3.00000 & $0.05408^{C D}$ & $0.19685^{B C}$ & $0.03532^{D}$ & $0.09542^{A}$ \\
\hline Mean & $0.01572^{B}$ & $0.08392^{B}$ & $0.19293^{A}$ & \\
\hline LSD: & $2,4-D=0.0827$ & $\mathbf{S A}=\mathbf{0 . 0 7 1 6}$ & $2,4-\mathrm{D} * \mathrm{SA}=0.1432$ & \\
\hline
\end{tabular}




\section{Total phenolic analysis}

Sustainable production of phytochemicals among the most studied groups of compounds regardless to their immense ability to protect against pathogenic attacks, to signal molecules and to control essential biochemical processes like antioxidants (15 and 26). The callus antioxidant activity and extraction of leaves belong to in vivo grown plants were calculated by using HPLC and applying the equation mentioned above. Results in Tables 4, 5, 6; Figure 1 and Figure 2 reveal to the highest concentration of keamferol and gallic acid compounds in callus of $S$. hispanica which occurred in the treatment with $2 \mathrm{mgl}^{-1}$ 2,4-D and $2 \mathrm{mgl}^{-1} \quad \mathrm{SA}$ in the presence of $0.5 \mathrm{mgl}^{-1}$ BA.

Table 4. In vitro and in vivo comparison antioxidant activity

\begin{tabular}{|cccccc|}
\hline Gallic acid & Catechin & Apiginine & Keamferol & Querceti & $\begin{array}{l}\text { The compounds } \\
\text { Part of Plant }\end{array}$ \\
\hline 70.539 & $\mathbf{5 1 4 . 8 6 0}$ & $\mathbf{9 2 . 5 8 9}$ & $\mathbf{3 4 6 . 2 6}$ & $\mathbf{1 1 7 3 . 9 4 1}$ & In vitro \\
40.345 & 1212.95 & 313.747 & 40.345 & 2947.54 & In vivo \\
$17.28 *$ & $146.02 *$ & $67.39 *$ & $55.62 *$ & $128.07 *$ & LSD 0.05 \\
\hline
\end{tabular}

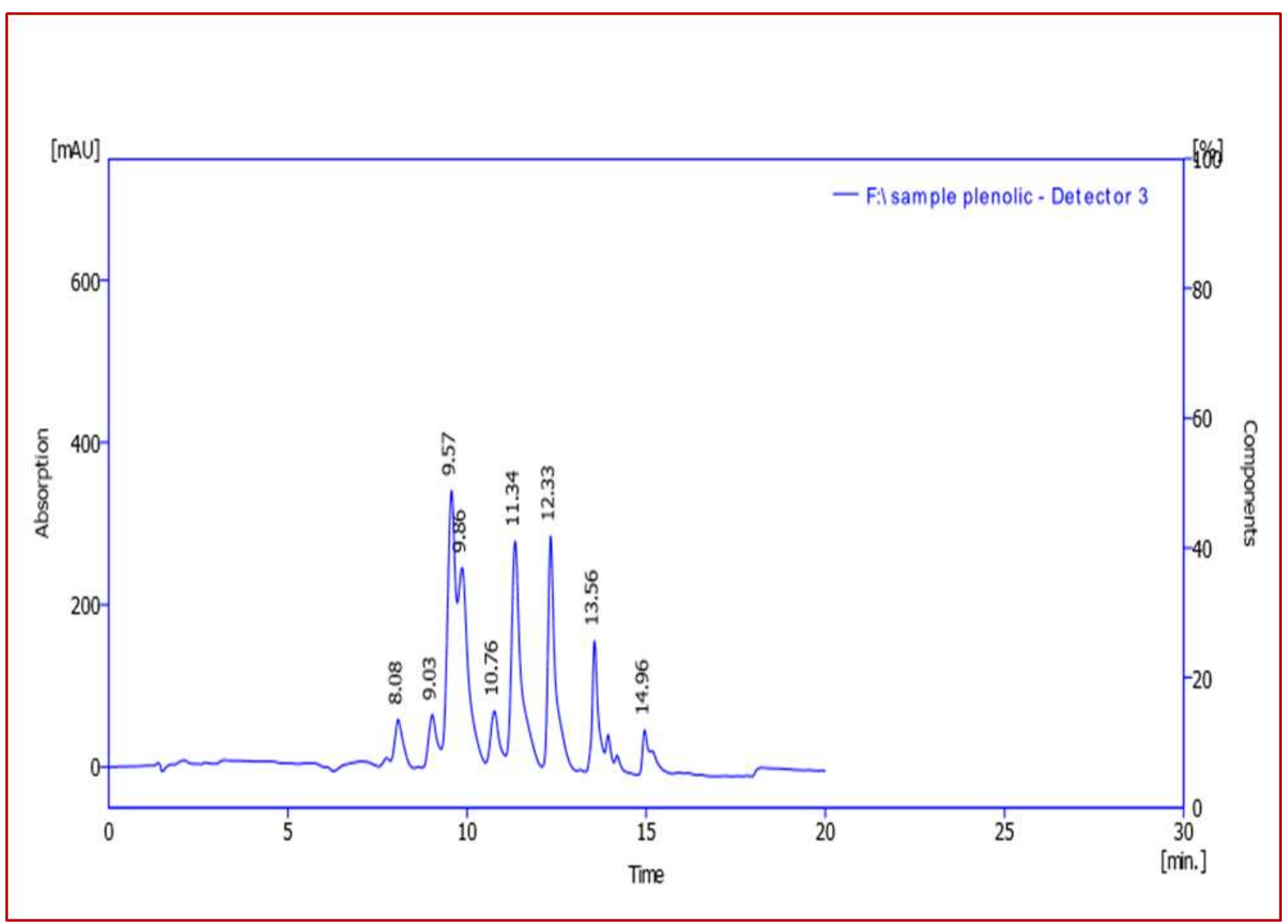

Figure 1. HPLC analysis of phenolic acids and flavonoids of leaves from in vivo grown plants Table 5. Phenolic acids and flavonoids of leaves from in vivo grown plants

\begin{tabular}{|ccc|}
\hline Compound & Retention time (minute) & Area \\
\hline Apiginine & $\mathbf{8 . 0 8 3}$ & $\mathbf{8 1 0 . 6 4 2}$ \\
Catechine & 9.567 & 1571.922 \\
Keamferol & 11.343 & 1956.910 \\
Qurcetine & 12.333 & 2474.006 \\
Gallic acid & 13.557 & 288.926 \\
\hline
\end{tabular}




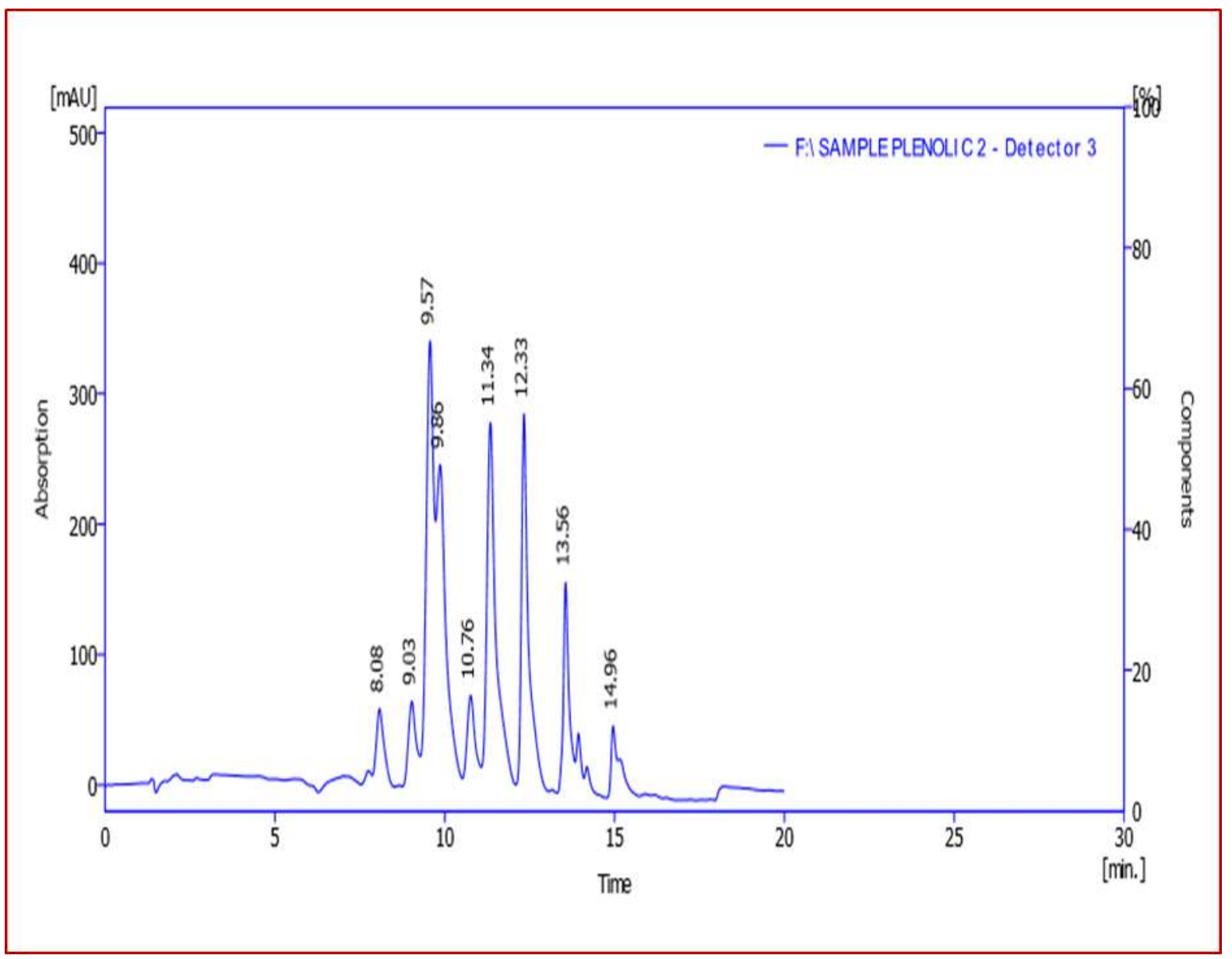

Figure 2. HPLC analysis of phenolic acids and flavonoids in callus from optimized treatment $\left[2,4-\mathrm{D}\left(2 \mathrm{mgl}^{-1}\right)\right.$ plus SA $\left(2 \mathrm{mgl}^{-1}\right)$

Tables 6. phenolic acids and flavonoids in callus from optimized treatment $\left[2,4-\mathrm{D}\left(2 \mathrm{mgl}^{-1}\right)\right.$ plus SA $\left.\left(2 \mathrm{mgl}^{-1}\right)\right]$

\begin{tabular}{|ccc|}
\hline Compound & Retention time (minute) & Area \\
\hline Apiginine & $\mathbf{8 . 0 8 3}$ & $\mathbf{5 3 1 . 8 0 4}$ \\
Catechine & 9.567 & 1483.303 \\
Keamferol & 11.343 & 1285.565 \\
Qurcetine & 12.333 & 2190.409 \\
Gallic acid & 13.557 & 1122.846 \\
\hline
\end{tabular}

It is very important to highlight that SA play a key role in phenolic and flavonoid compounds production and stimulates the plant endogenous enzymes (1 and 14), as for example, SOD (Super Oxide Dismutase) which is a defensive system in plant for Reactive Oxygen Species (ROS)(10). Also, it should be noticed that a low concentrations of catechin, apiginine and querceti compounds was observed in in vitro tissues in the presence of PGRs and SA compared to the in vivo leaves which lacked to PGRs and SA. The explanation for the great response in case of in vivo compared with in vitro might be that $\mathrm{SA}$ is the regulator of plant growth and it's exogenous application stimulates the main growth (26) and had (in the presence of PGRs) a negative response on the production of those three phenolic compounds.

\section{CONCLUSION}

The results of this study showed, it can be concluded that the experimental conditions used in current research allowed the putative detection of polyphenolic compounds of in vitro and in vivo grown plant leaves extract of Salvia hispanica based on their mass fragmentation trend, retention time and UV spectrum. Five phenolic acid compounds derivatives were identified in the crude extract, namely catechin, apiginine, querceti, keamferol and gallic acid their concentrations vary between in vitro and in vivo. Future 
studies may be conducted to develop and research secondary metabolites in the in vivo and in vitro culture of $S$. hispanica, with the goal of further understanding and discovering the medicinal functions and property of this plant species.

\section{REFERENCES}

1. A.K.Hamood and B.H.Majeed. 2017. Effect of Benzyl adenine and salicylic acid on growth and total alkaloids production of Wethinia (Withania somnifera L.) in vitro. The Iraqi Journal of Agricultural Sciences. 48(1): 256265

2. Actros Specimen Database. 2018. Collaborative collection management solution. Retrieved from http://arctos.database.museum/name/Salvia\%h ispanica.

3. Bárbara N. Enes; Luiza P. D. Moreira; Bárbara P. Silva; Mariana Grancieri; Haira G. Lúcio; Vinícius P. Venâncio; Susanne U. Mertens-Talcott; Carla O. B. Rosa and Hércia S. D. Martino. 2020. Chia seed (Salvia hispanica L.) effects and their molecular mechanisms on unbalanced diet experimental studies: A systematic review. Journal of food science. 85(2): 226-239

4. Budhiraja, R.P. 2004. Separation Chemistry. New Age International LTD., ublishers, New Delhi. 171-239

5. Busilacchi, H.; M.Quiroga,; M.Bueno,; O.Di Sapio,; V.Flores, and C. Severin, 2013. Evaluation of Salvia hispanica L. cultivated in the South of Santa Fe (Argentina). Cultivos Tropicales. 34(4): 55-59

6. Ca Dodds JH and LW Roberts. 1985. Experiments in Plant Tissue Culture. Cambridge University Press, Cambridge

7. Carew, D.P. and R. Krueger. 1977. Catharanthus roseus tissue culture the effect of medium modification on growth and alkaloid production. J. Nat. Prod. 40(4): 326336

8. da Silva, B. P.; P. C. Anunciac, ao; J. C. D. S Matyelka;.; C. M. Della Lucia; Mar- tino, H. S. D. and , H. M. Pinheiro-Sant'Ana. 2017. Chemical composition of Brazilian chia seeds grown in different places. Food Chemistry. 221: 1709-1716.

9. da Silva, B. P.; R. C. L.Toledo,; M. Grancieri,; M. E. D. C. Moreira; N. R. Medina,; R. R. Silva, and H. S. D Martino.
2018. Effects of chia (Salvia hispanica L.) on calcium bioavailability and inflammation in Wistar rats. Food Research International. 116: 592- 599

10. Fazal, H.; B. H. Abbasi; N. Ahmad and M. Ali. 2016. Elicitation of medicinally important antioxidant secondary metabolites with silver and gold nanoparticles in callus cultures of Prunella vulgaris L. Appl. Biochem. Biotechnol. 180: 1076-1092

11. Goodwin, M. 1985. Introduction to Plant Biochemistry. $2^{\text {nd }}$ ed. Pergamum press. New York. 1-3

12. Gupta M.; S. Sasma; Majumdar Sohinil and A. Mukherjee. 2012. HPLC Profiles of standard phenolic compounds Present in Medicinal plants. International Journal of Pharmacognosy and Phytochemical Research. 4(3): 162-167

13. Hala Jumaah Asree; H. Amirah Imran.; Ali Abed Gatea and Ahmed Ali Khirallah. 2019. In vitro induced callus of Thevetia neriifolia Juss. Plant Archives. 19(2): 642-645. 14. Jaddo, Z. I. and K. M. Rabee. 2016. Effect of salicylic and humic acid on vincristine and N, P, K Content in Madagascar periwinkle leaves. The Iraqi Journal of Agricultural Sciences, 47(2): 543-551

15. Karabourniotis, G.; G. Liakopoulos; D. Nikolopoulos; P. Bresta; V. Stavroulaki and S. Sumbele. 2014. Carbon gain vs. water saving, growth vs. defense: Two dilemmas with soluble phenolic as a joker. Plant Sci. 227: 2127.

16. Marineli, R. S.; , S. A.Lenquiste, E. A. Moraes and . M. R. Jr. Maróstica. 2015. Antioxidant potential of dietary chia seed and oil (Salvia hispanica L.) in diet induced obese rats. Food Research International. 76: 666-674 17. Marineli, R. S.; E. A. Moraes; S. A. Lenquiste; A. T. Godoy; M. N. Eberlin and M. R Maróstica. 2014. Chemical characterization and antioxidant potential of Chilean chia seeds and oil (Salvia hispanica L.). LWT=Food Science and Technology. 59(2): 1304-1310.

18. Masoomeh Modarres and Ziba Ghasimi Hagh. 2019. Investigation of the effect of light, phenylalanine and caffeic acid on the production of phenolic acids in cell suspension culture of Salvia leriifolia j. Plant Proc. Func. 8(29):171-179. 
19. Murashige, T. and F. Skoog. 1962. A revised medium for rapid growth and bioassays with tobacco tissue cultures. Physiol. Plant. 15: 473-497.

20. Neha Tiwari; Nidhi Srivastava and Vinay Sharma. 2014. Comparative analysis of total phenolic content and antioxidant activity of in vivo and in vitro grown plant parts of Carica papaya L. Ind. J. Plant Physiol. 19(4):356362

21. Poudyal, H.; S. K. Panchal; J Waanders; L. Ward, and L. Brown. 2012. Lipid redistribution by a-linolenic acid-rich chia seed inhibits stearoyl-CoA desaturase-1 and induces cardiac and hepatic protection in dietinduced obese rats. Journal of Nutritional Biochemistry. 23: 153-162

22. RS. R. KH .Al-Khazali and M. S. Hamad. 2016. Influence of growth regulators on callus induction of citrus Volkameriana in vitro. The Iraqi Journal of Agricultural Sciences. 47(3): 723-731
23. Scalbert, A. and G. Williamson. 2000. Dietary intake and bioavailability of polyphenols. Journal of Nutrition. 130: 2073S$2085 \mathrm{~S}$

24. Shadab G, Jahromi. 2019. Extractions techniques of phenolic compounds from plants. DOI: 10.5772/intechopen. 84705. p. 25. 25. Shivkumar, S.I.; H. M. Suresh; BM. Vrushabendra Swamy; G. S. Kumar; R. Dhanapa; V. L. Ashokbabu and V. Rao. 2006. Hepatoprotective activity of fruits of Cocinia grandis Linn. against carbon tetrachloride induced heptatoxicity. J. Adv. Pharmacol. Toxicol. 7(2): 7-9

26. Taimoor Khana; Tariq Khana; Christophe Hanob and Bilal Haider Abbasi. 2019. Effects of chitosan and salicylic acid on the production of pharmacologically attractive secondary metabolites in callus cultures of Fagonia indica. Industrial Crops \& Products. 129: 525-535. 